\title{
A Comparison of Ethanol, Methanol and Butanol BLENDING WITH GASOLINE AND RELATIONSHIP WITH ENGINE PERFORMANCES AND EMISSIONS
}

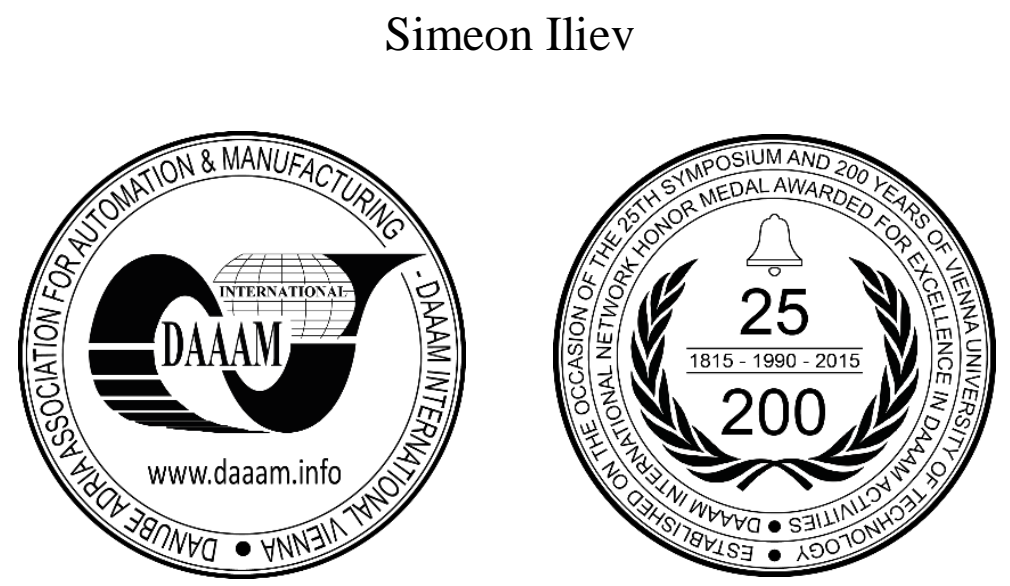

This Publication has to be referred as: Iliev, S[imeon] (2018). A Comparison of Ethanol, Methanol and Butanol Blending with Gasoline and Relationship with Engine Performances and Emissions, Proceedings of the 29th DAAAM International Symposium, pp.0505-0514, B. Katalinic (Ed.), Published by DAAAM International, ISBN 978-3-90273420-4, ISSN 1726-9679, Vienna, Austria

DOI: $10.2507 / 29$ th.daaam.proceedings.073

\begin{abstract}
Worldwide, in recent years, it has been observed intensive research to find out alternatives to fossil fuels because world's fossil fuel reserves are limited. Alternative fuels are derived from resources other than petroleum. Alcohol based fuels may have been regarded as one of the alternative fuels because they have several physical and combustion properties similar to gasoline. The use of alcohol fuels or alcohol-blended fuels in gasoline has a great potential to reduce engine emissions. That is why this study is aimed to develop the model of a spark-ignited engine for predicting the effect of various fuel types on engine performances and emissions. The simulation tool AVL Boost was used to analyze the engine characteristics for different blends of ethanol, methanol, butanol and gasoline (by volume). The simulation results obtained from different fuel blends indicated that when alcohol-gasoline fuel blends were used, the brake power decreased and the brake specific fuel consumption increased compared to those of gasoline fuel. When fuel blends percentage increases, the $\mathrm{CO}$ and $\mathrm{HC}$ concentration decreases.
\end{abstract}

Keywords: alternative fuels; methanol blends; ethanol blends; butanol blends; spark-ignition engine

\section{Introduction}

The exhaust gases from internal combustion engines (ICEs), affect environment and human life negatively and they become a great problem. The most harmful pollutant gases, produced from engines, are carbon monoxide (CO), nitrogen oxides (NOx), hydrocarbons ( $\mathrm{HC}$ ), and particles pollutants. Because $\mathrm{CO}_{2}$ emissions reason global warming, which is one of the global environmental problems; it is estimate as a pollutant. Many researchers have focused to finding ways to reduce emissions from fossil fuels. Among the alternatives, oxygenates have shown potential to reduce emission levels without sacrificing power [1]. The use of fuel additives is very important because many of these additives can be added to fuel in order to improve its efficiency and performance. Some of the most important additives to improve fuel performance are oxygen containing organic compounds (oxygenates) [2]. Several oxygenates have been used as fuel additives, such as methanol, ethanol, tertiary butyl alcohol and methyl tertiary butyl ether [3]. The use of oxygenated fuel additives provides more oxygen in the combustion chamber and has a great potential to reduce emissions from spark ignition (SI) and compression ignition engines [4]. Methanol, ethanol, butanol and biodiesel are main biofuels. 
The first four aliphatic alcohols (methanol, ethanol, propanol, and butanol) are of interest as fuels because they can be synthesized chemically or biologically, and they have characteristics, which allow them to be used in current engines. Alcohols are liquid fuel and can work in the internal combustion engine (ICE) with gasoline without requiring major modification. The three alcohols ethanol, methanol and butanol will be used as alternative fuels in pure form or in the form of blending with conventional fuels in future to reduce the demand for conventional fuels [5]. Fossil fuels have some disadvantages compared to alcohol fuels. This fuel has lower octane number and emits much more harmful emissions than alcohol fuels. Due to having much more physical and chemical divers than alcohol, complex refining processes are required to ensure the consistent production of gasoline from petroleum fuel [6]. Due to having high oxygen content, high stoichiometric air/fuel ratio, high hydrogen-carbon ratio and low sulphur content, alcohol emits less emission (Table 1). On the combustion characteristics, the auto-ignition temperature and flash point of ethanol, methanol and butanol are higher than those of gasoline, which makes it safer for transportation and storage [9]. Methanol, ethanol and butanol have higher heat of vaporization than gasoline; this makes the temperature of the intake manifold much lower, which results in cooling effect in the intake and compression stroke. As a result, the volumetric efficiency of the engine is increased and the required amount of the work input is reduced in the compression stroke. Alcohols have high laminar flame propagation speed, which may complete the combustion process earlier. This improves engine thermal efficiency [10].

\begin{tabular}{|l|c|c|c|c|}
\hline Properties & Gasoline & Methanol & Ethanol & Butanol \\
\hline Chemical formula & $\mathrm{C}_{8} \mathrm{H}_{15}$ & $\mathrm{CH}_{3} \mathrm{OH}$ & $\mathrm{C}_{2} \mathrm{H}_{5} \mathrm{OH}$ & $\mathrm{C}_{4} \mathrm{H}_{9} \mathrm{OH}$ \\
\hline Molecular weight & 111.21 & 32.04 & 46.07 & 74.12 \\
\hline Oxygen content, wt\% & - & 49.93 & 34.73 & 21.59 \\
\hline Density, g/cm & & 0.792 & 0.785 & 0.811 \\
\hline Carbon content, wt\% & 0.737 & 37.5 & 52.2 & 64.8 \\
\hline Hydrogen content, wt\% & 86.3 & 12.5 & 13.1 & 13.5 \\
\hline Stoichiometric AFR & 24.8 & 6.43 & 8.94 & 11.12 \\
\hline Lower heating value, $\mathrm{Mj} / \mathrm{kg}$ & 14.5 & 20 & 27 & 33 \\
\hline Heat of evaporation, $\mathrm{kj} / \mathrm{kg}$ & 44.3 & 1178 & 840 & 578.4 \\
\hline Octane number $(\mathrm{RON}+\mathrm{MON}) / 2$ & 305 & 99 & 100 & 86 \\
\hline Vapor pressure $\left(\mathrm{psi}\right.$ at $\left.37.7^{\circ} \mathrm{C}\right)$ & 4.5 & 4.6 & 2 & 0.33 \\
\hline Specific gravity $\left(\mathrm{kg} / \mathrm{dm}^{3}\right)$ & 0,7430 & 0,7913 & 0,7894 & 0,8097 \\
\hline Auto-ignition temperature $\left({ }^{\circ} \mathrm{C}\right)$ & $246-280$ & 470 & 365 & 345 \\
\hline
\end{tabular}

Table 1. Comparison of various properties of primary alcohol fuels with gasoline [7], [8]

Form Table 1, it can be said that about the latent heat of vaporization of these fuels, butanol is less attractive than others are. For PFI (port fuel injection) systems, fuels with higher latent heat of vaporization have larger decreases in temperature of intake charge with complete vaporization in the intake port. To match the combustion characteristics of gasoline, the utilization of butanol fuel as a substitute for gasoline requires fuel-flow increases (though butanol has only slightly less energy than gasoline, so the fuel-flow increase required is only minimal, maybe 10\%). Higher oxygen content and lower octane number of n-butanol need changes in initial engine calibration, determined with pure gasoline. In addition, butanol has a higher laminar flame propagation speed than gasoline, which makes combustion process finish earlier and improving the engine thermal efficiency. Moreover, the use of bio-based products in fuels is a strategic government resolution in most European countries. According to the Act [11] and the EU Directive [12] bio-components meet the criterion of reducing greenhouse gases, if it reaches a level of at least 35\% until 31 December 2016, 50\% from 1 January 2017 and at least 60\% from 1 January 2018, for biofuels and bio liquids produced in installations in which production started on 1 January 2017 or later. According to the Directive [12] biofuels should be used for reducing greenhouse gas emissions to at least $6 \%$ by 31 December 2020, compared to the EU average of greenhouse gas emissions throughout the life cycle per unit of energy from fossil fuels in 2010. BP and DuPont announced that they would start selling n-butanol, under the name of biobutanol, as a gasoline-blending component in the UK while ethanol is already commonly used. The Renewable Fuel Standard under the Energy Independence and Security Act of 2007 mandates an increase in the volume of renewable fuel to be blended into transportation fuel from 9 billion gallons in 2008 to 36 billion gallons by 2022 [13] and [14]. There is plenty of literature to various blends of ethanol, methanol, butanol and gasoline utilization in gasoline engines. Altun et al. [15] studied the effect of 5\% and $10 \%$ ethanol and methanol blending in unleaded gasoline on engine performance and exhaust emission. 
Results indicated that M10 and E10 blended fuels demonstrated the best result in exhaust emission. The HC emission of M10 and E10 are reduced by $13 \%$ and $15 \%$ and the $\mathrm{CO}$ emissions by $10,6 \%$ and 9,8\%, respectively. Increased $\mathrm{CO}_{2}$ emission for M10 and E10 compared with unleaded gasoline was observed. The ethanol and methanol addition to unleaded gasoline demonstrated an increase of BSFC (brake specific fuel consumption) and a decrease of break thermal efficiency in comparison to unleaded gasoline. In another study, Feng et al. [16] for pure gasoline and 35\% by volume butanol-gasoline blend. The results showed that engine torque, brake specific fuel consumption (BSFC) and CO and HC emissions were better than those of pure gasoline at both full load and partial load with $35 \%$ volume butanol addition. But $\mathrm{CO}_{2}$ emission was worse than that of the original level of pure gasoline. Gravalos et al. [17] conducted several tests with SI engine with lower to higher mass alcohol blends with fixed percentages of $1.9 \%$ methanol, $3.5 \%$ propanol, 1.5 $\%$ butanol, and $1.1 \%$ pentanol, along with a varying percentage of ethanol from $2 \%$ to $22 \%$ in increments of $5 \%$. The $2 \%$ ethanol blend produced maximum $\mathrm{CO}$ and $\mathrm{HC}$ emissions and lower $\mathrm{CO}_{2}$ and $\mathrm{NO}_{\mathrm{x}}$ emissions. In another experiment, they removed the higher mass alcohols (i.e., propanol, butanol, and pentanol) and conducted experiments with just lower mass alcohols. These lower mass alcohols produced lower $\mathrm{HC}, \mathrm{CO}_{2}$, and $\mathrm{NOx}$ emissions and higher $\mathrm{CO}$ emissions compared with the lower to higher mass alcohol blends. Costagliola et al. [18] examined 10\% n-butanol (as well as different ethanol blends) in a PFI engine showing similar benefits in CO, HC, and PM emissions as with ethanol, but also similar increases in carbonyl emissions.

\section{Research Methodology}

The present paper aims to develop the 1-D combustion model of four-stroke port fuel injection (PFI) gasoline engine for predicting the effect of methanol-gasoline (M0, M5, M10, M20, M30 and M50), ethanol-gasoline (E0, E5, E10, E20, E30 and E50) and butanol-gasoline (B0, B5, B10, B20, B30 and B50) fuel blends on the performance and emissions of SI engine. For this purpose, a simulation of calibrated gasoline engine model was used as basic operating condition and the laminar burning velocity correlations of methanol-gasoline, ethanol-gasoline and butanol-gasoline fuel blends for calculating the changed combustion duration. The engine performances: torque and specific fuel consumption were compared and discussed.

\subsection{Simulation Setup}

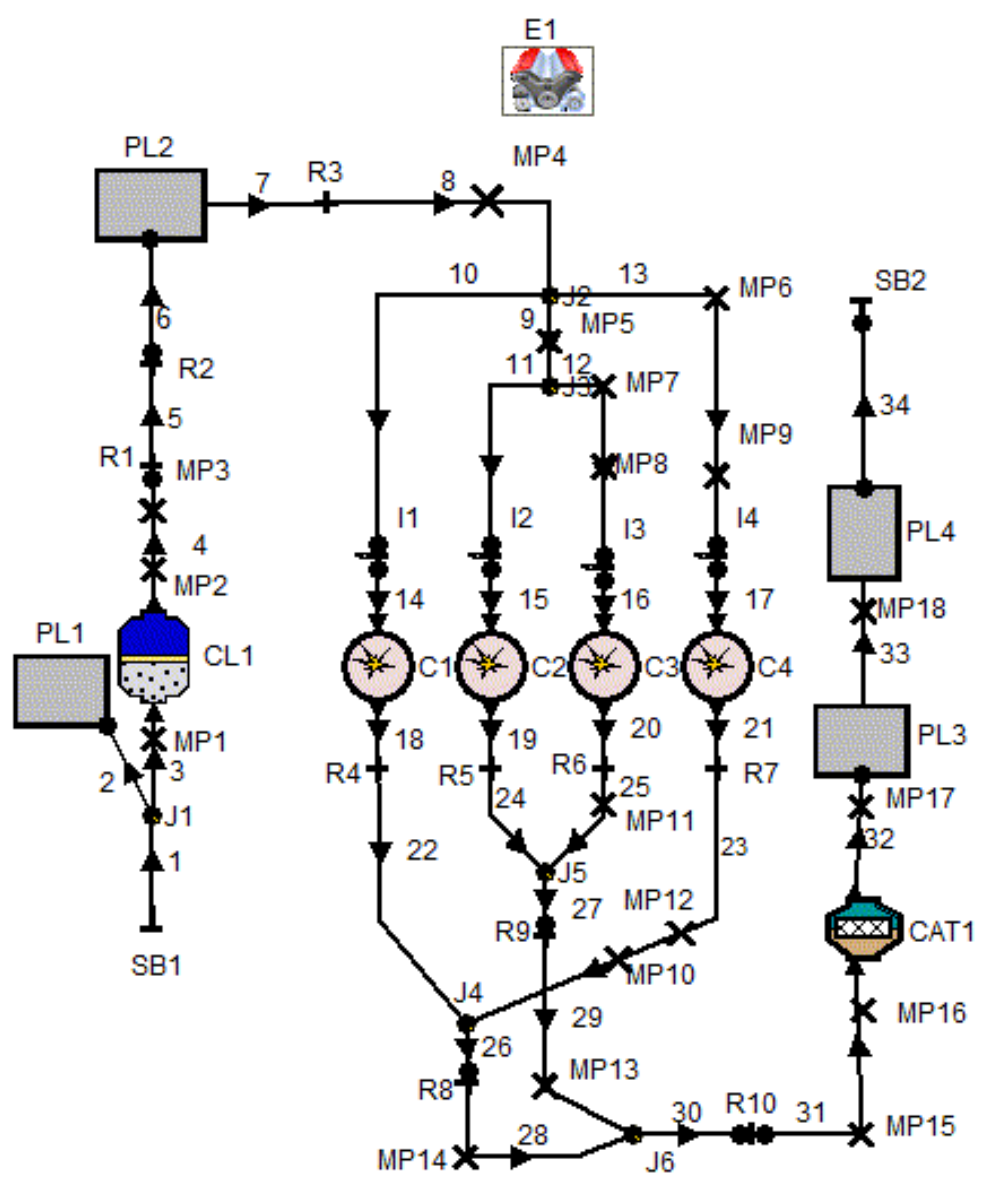

Fig. 1. Layout of gasoline PFI engine model. 
The 1-D engine simulation model is developed by using the software AVL BOOST and has been employed to study the performance of an engine working on methanol-gasoline, ethanol-gasoline and butanol-gasoline blends. The preprocessing step of AVL Boost enable the user to model a 1-Dimensional engine test bench setup using the predefined elements provided in the software toolbox. The various elements are joined by the desired connectors to establish the complete engine model using pipelines. In (Fig.1), E1 represents the engine while C1, C2, C3 and C4 represent the number of cylinders of the engine. MP1 to MP18 represent the measuring points. PL1, PL2, PL3 and PL4 represent the plenum. SB1 and SB2 are for the system boundary. The flow pipes are numbered 1 to 34. CL1 represents the cleaner. R1 to R10 represent flow restrictions, CAT1 represents catalyst and I1 to I4 represent fuel injectors. The engine model used in this simulation was performed on a four stroke, four cylinder spark ignition engine with port fuel injection. The gasoline engine model was calibrated and described by Iliev [19] and its layout is shown in (Fig. 1) with engine specification shown in Table 2.

\begin{tabular}{|l|c|}
\hline Engine parameters & Value \\
\hline Bore & $86(\mathrm{~mm})$ \\
\hline Stroke & $86(\mathrm{~mm})$ \\
\hline Compression ratio & 10,5 \\
\hline Connection rod length & $143,5(\mathrm{~mm})$ \\
\hline Number of cylinder & 4 \\
\hline Piston pin offset & $0(\mathrm{~mm})$ \\
\hline Displacement & $2000(\mathrm{cc})$ \\
\hline Intake valve open & $20 \mathrm{BTDC}(\mathrm{deg})$ \\
\hline Intake valve close & $70 \mathrm{ABDC}(\mathrm{deg})$ \\
\hline Exhaust valve open & $50 \mathrm{BBDC}(\mathrm{deg})$ \\
\hline Exhaust valve close & $30 \mathrm{ATDC}^{(\mathrm{deg})}$ \\
\hline Piston surface area & $5809\left(\mathrm{~mm}^{2}\right)$ \\
\hline Cylinder surface area & $7550\left(\mathrm{~mm}{ }^{2}\right)$ \\
\hline Number of stroke & 4 \\
\hline
\end{tabular}

Table 2. PFI engine specification.

\section{Result and discussion}

The present study concentrated on the emission and performance characteristics of the methanol, ethanol and butanolgasoline blends. Different concentrations of the blends 0\% Ethanol (Methanol, Butanol) E0 (M0, B0), 5\% Ethanol (Methanol, Butanol) E5 (M5, B5), 10\% Ethanol (Methanol, Butanol) E10 (M10, B10), 20\% Ethanol (Methanol, Butanol) E20 (M20, B20), 30\% Ethanol (Methanol, Butanol) E30 (M30, B30), 50\% Ethanol (Methanol, Butanol) E50 (M50, B50) and 85\% Ethanol (Methanol, Butanol) E85 (M85, B85) by volume were analysed using AVL BOOST at full load conditions for the speeds ranging from $1000-6500 \mathrm{rpm}$ in the steps of $500 \mathrm{rpm}$.

\subsection{Engine performance characteristics}

The results of the brake power, and specific fuel consumption for methanol, ethanol and butanol gasoline blended fuels at different engine speeds are presented here. Fig. 2 shows the influence of methanol, ethanol and butanol gasoline blended fuels on engine brake power.

The brake power is one of the important factors that determine the performance of an engine. The variation of brake power with speed was obtained at full load conditions for E5 (M5, B5), E10 (M10, B10), E20 (M20, B20), E30 (M30, $\mathrm{B} 30$ ), E50 (M50, B50) and pure gasoline E0 (M0, B0), using the CFD results.

When the ethanol content in the blended fuel was increased, the engine brake power decreased for all engine speeds. The brake power of gasoline was higher than those of E5-E50 for all engine speeds. The heating value of ethanol is lower than that of gasoline and heating value of the blended fuel decreases with the increase of the ethanol content. As a result, a lower power output is obtained [19] and [20].

When the methanol content in the blended fuel was increased (M5 and M10), the engine brake power slightly increased. This can be explained by the fact that oxygenated fuels have a better combustion efficiency. When the methanol content in the blended fuel was increased (M30 and M50), the engine brake power decreased for all engine speeds. The heating value of the blended fuel decreases with the increase of the methanol content. As a result, a lower power output is obtained. The brake power of gasoline was higher than those of M50 for all engine speeds. 
When the n-Butanol content in the blended fuel was increased, the engine brake power decreased for all engine speeds. The brake power of gasoline was higher comparisons of B5 to B85 for all engine speeds.

Butanol addition to the gasoline does not affect engine power significantly, but especially at high engine speed (over $4000 \mathrm{~min}^{-1}$ ), there is a sharp reduction the power curves compared to pure gasoline (Fig. 2). The reason of this reduction can be affected by the low calorific value of butanol. This may refer to some reasons as follows. Combustion characteristic of n-butanol is different from gasoline since the latent heat of n-butanol is higher than that for gasoline $(584 \mathrm{~kJ} / \mathrm{kg}, 349$ $\mathrm{kJ} / \mathrm{kg}$ for $\mathrm{n}$-butanol and gasoline, respectively). This means that the $\mathrm{n}$-butanol absorbs more heat in order to evaporate and burn.
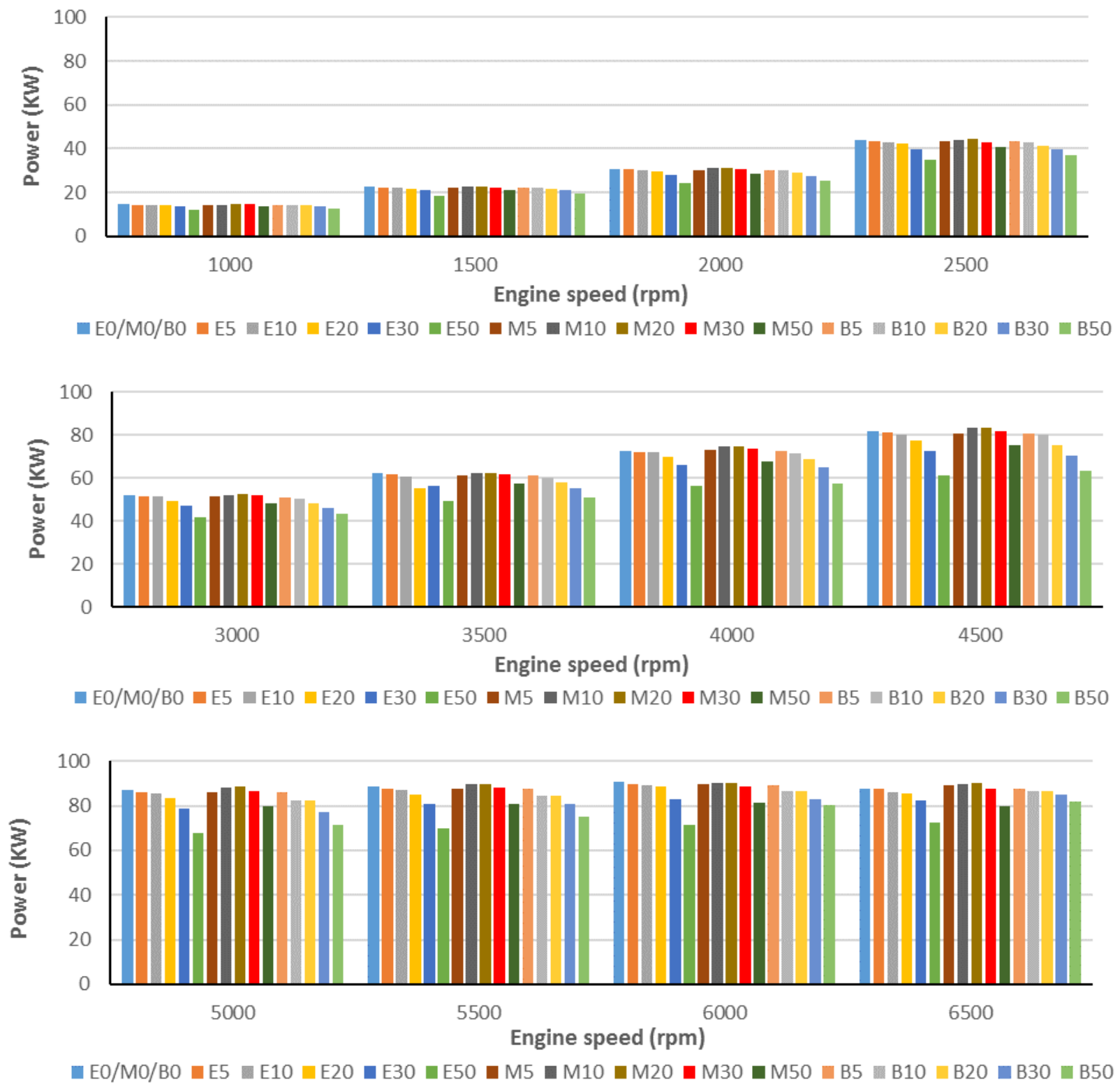

Fig. 2. Influence of ethanol, methanol and butanol gasoline blended fuels on engine brake power.

Fig. 3 indicates the variations of the BSFC for methanol, ethanol and butanol gasoline blended fuels under various engine speeds. As shown in this figure, the BSFC increased as the ethanol percentage increased. The reason is well known: the heating value and stoichiometric air-fuel ratio are the smallest for this fuel, which means that for specific air-fuel equivalence ratio, more fuel is needed. The highest specific fuel consumption is obtained at E50 (M50) blended fuel.

Also, a slight difference exists between the BSFC when using gasoline and when using ethanol, methanol and butanol gasoline blended fuels (E5 (M5, B5), E10 (M10, B5) and E20 (M20, B5)). The lower energy content of ethanol, methanol and butanol gasoline blended fuels causes some increment in BSFC of the engine when it is used without any modification. The highest specific fuel consumption for butanol's blended fuel is obtained for B50 blended fuel. 

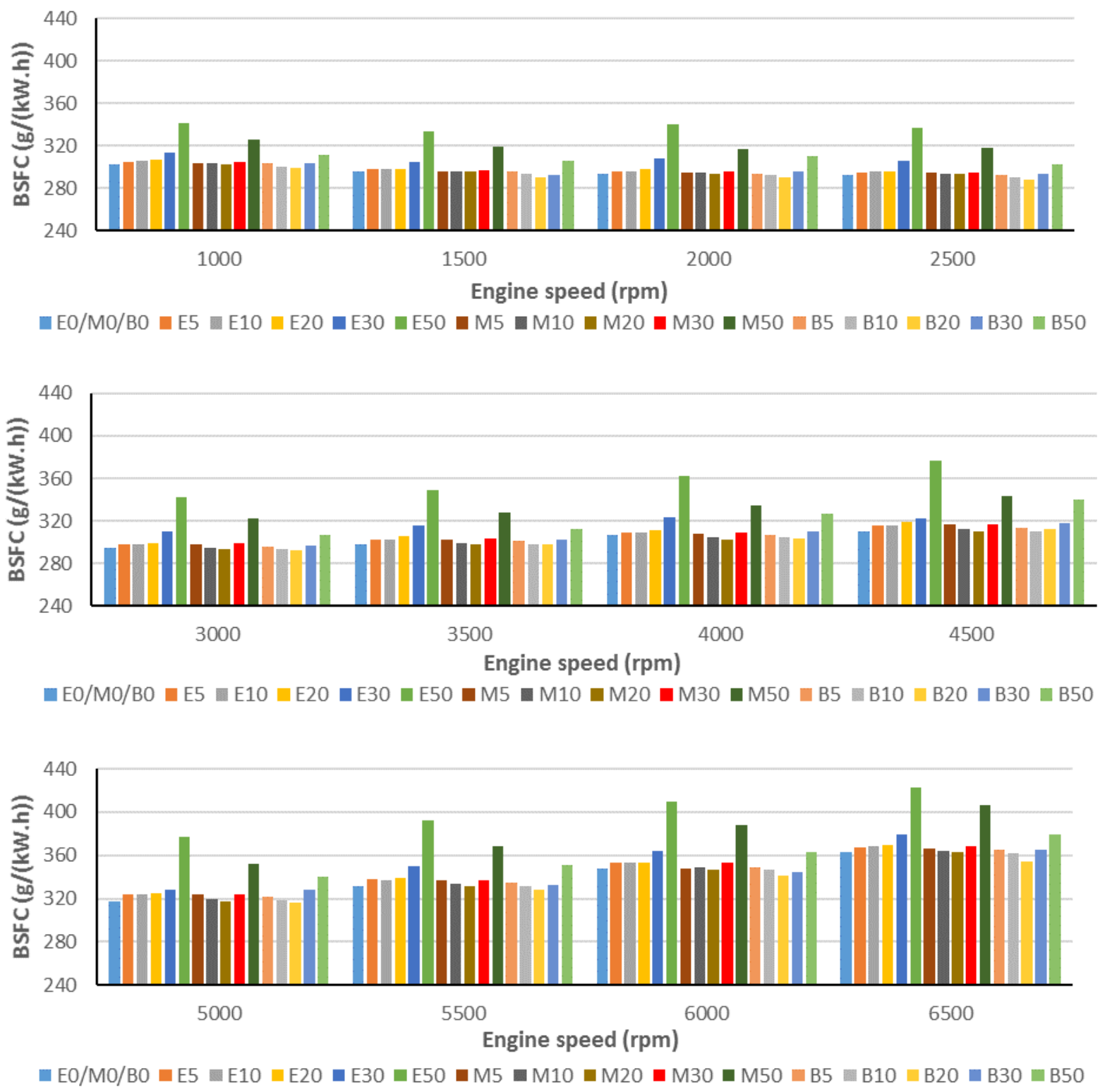

Fig. 3. Influence of ethanol, methanol and butanol gasoline blended fuels on brake specific fuel consumption.

\subsection{Engine emissions characteristics}

Fuels consist of Hydrogen (H) and Carbon (C) molecules. During the combustion period in the engine cylinder, these $\mathrm{C}$ and $\mathrm{H}$ molecules react with oxygen $(\mathrm{O} 2)$ in the air and converted to the $\mathrm{CO}, \mathrm{CO} 2, \mathrm{HC}$. These exhaust tail emissions are harmful for human health and environmental pollution. Carbon monoxide $(\mathrm{CO})$ is colorless, odorless, tasteless gas which is lighter than air. It is highly toxic to humans and animals in higher quantities. $\mathrm{CO}$ is a common industrial hazard resulting from the incomplete burning of natural gas and any other material containing carbon.

The effect of the ethanol, methanol and butanol gasoline blends on $\mathrm{CO}$ emissions for different engine speeds is shown in (Fig. 4). It can be seen that when ethanol, methanol and butanol percentage increases, the CO concentration decreases. This can be explained by the enrichment of oxygen owing to the ethanol methanol and butanol, in which an increase in the proportion of oxygen will promote the further oxidation of $\mathrm{CO}$ during the engine exhaust process. Another significant reason for this reduction is that ethanol $\left(\mathrm{C}_{2} \mathrm{H}_{5} \mathrm{OH}\right)$, methanol $\left(\mathrm{CH}_{3} \mathrm{OH}\right)$ and butanol $\left(\mathrm{C}_{4} \mathrm{H}_{9} \mathrm{OH}\right)$ has less carbon than gasoline $\left(\mathrm{C}_{8} \mathrm{H}_{18}\right)$. The lowest $\mathrm{CO}$ emissions are obtained with blended fuel containing methanol (M50). 

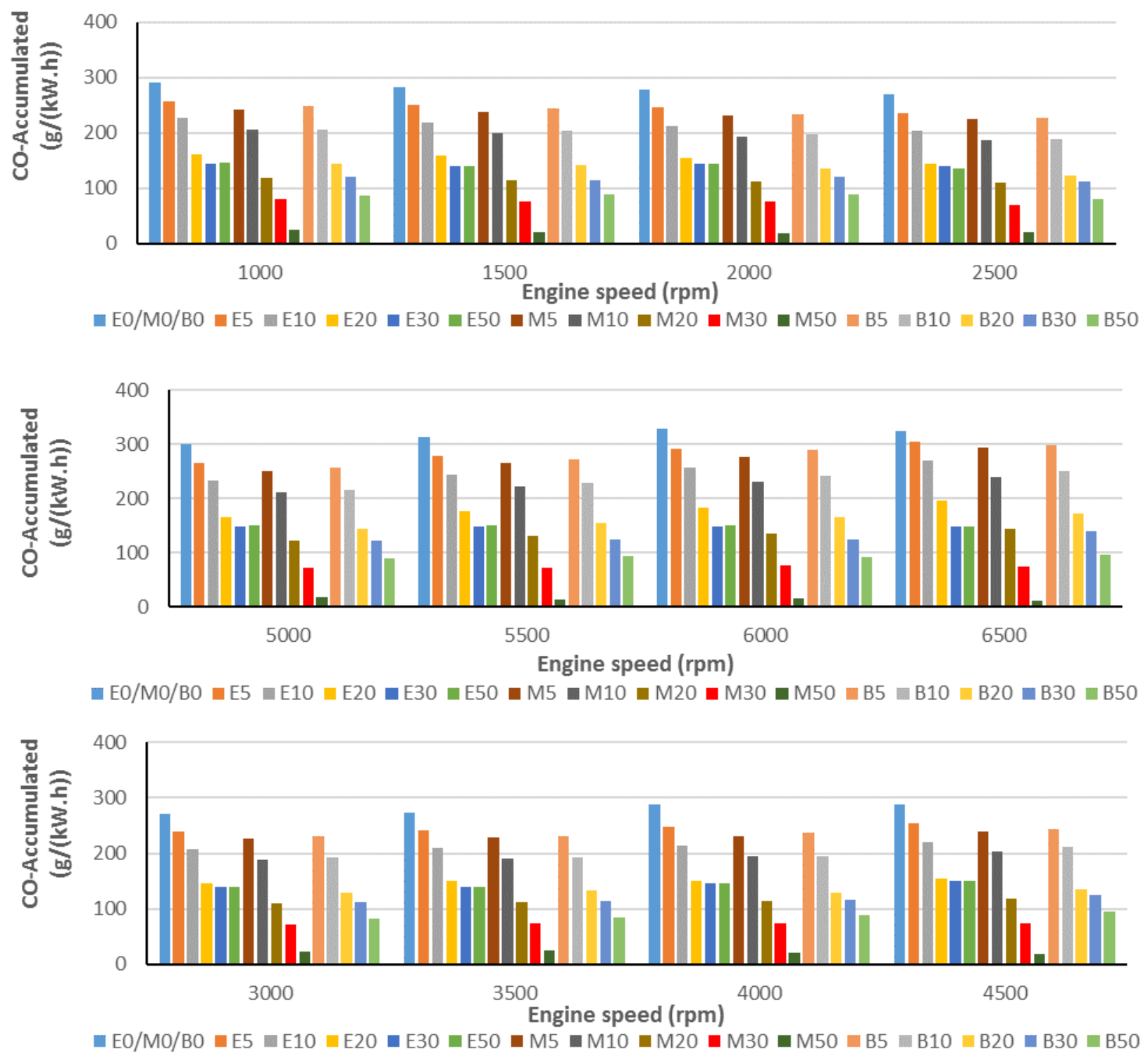

Fig. 4. Influence of ethanol, methanol and butanol gasoline blended fuels on $\mathrm{CO}$ emissions.

The effect of the ethanol and methanol gasoline blends on HC emissions for different engine speeds is shown in (Fig. 5). It can be seen that when ethanol, methanol and butanol percentage increases, the HC concentration decreases. The concentration of $\mathrm{HC}$ emissions decreases with the increase of the relative air-fuel ratio. The reason for the decrease of $\mathrm{HC}$ concentration is similar to that of $\mathrm{CO}$ concentration described above. The comparison of decrease of HC emissions among the blended fuels indicates that methanol is more effective than ethanol and butanol. The lowest HC emissions are obtained with blended fuel containing methanol (M50). When the complete combustion is more, the HC emission is lower.

When using gasoline as fuel in a spark ignition engine, the unburned fuel hydrocarbons (HC) in the exhaust consist mainly of unburned gasoline which itself largely consists of hydrocarbons. However, when using gasoline-Butanol blends as fuel the uncombusted fuel constituents include both unburned gasoline (which consists mainly of hydrocarbons as noted) and un-combusted Butanol. Thus, the HC emissions measured in the diluted exhaust consist of both hydrocarbons and Butanol. From a legal perspective, HC emissions are regulated by law, but not butanol emissions. This means that reported $\mathrm{HC}$ emissions from vehicles fueled with alcohol-gasoline blends are overestimated, due to the contribution of the alcohol contents in the exhaust emitted from the vehicle, and the larger the alcohol contents present in the exhaust, the greater the error in estimated HC emissions [21]. 

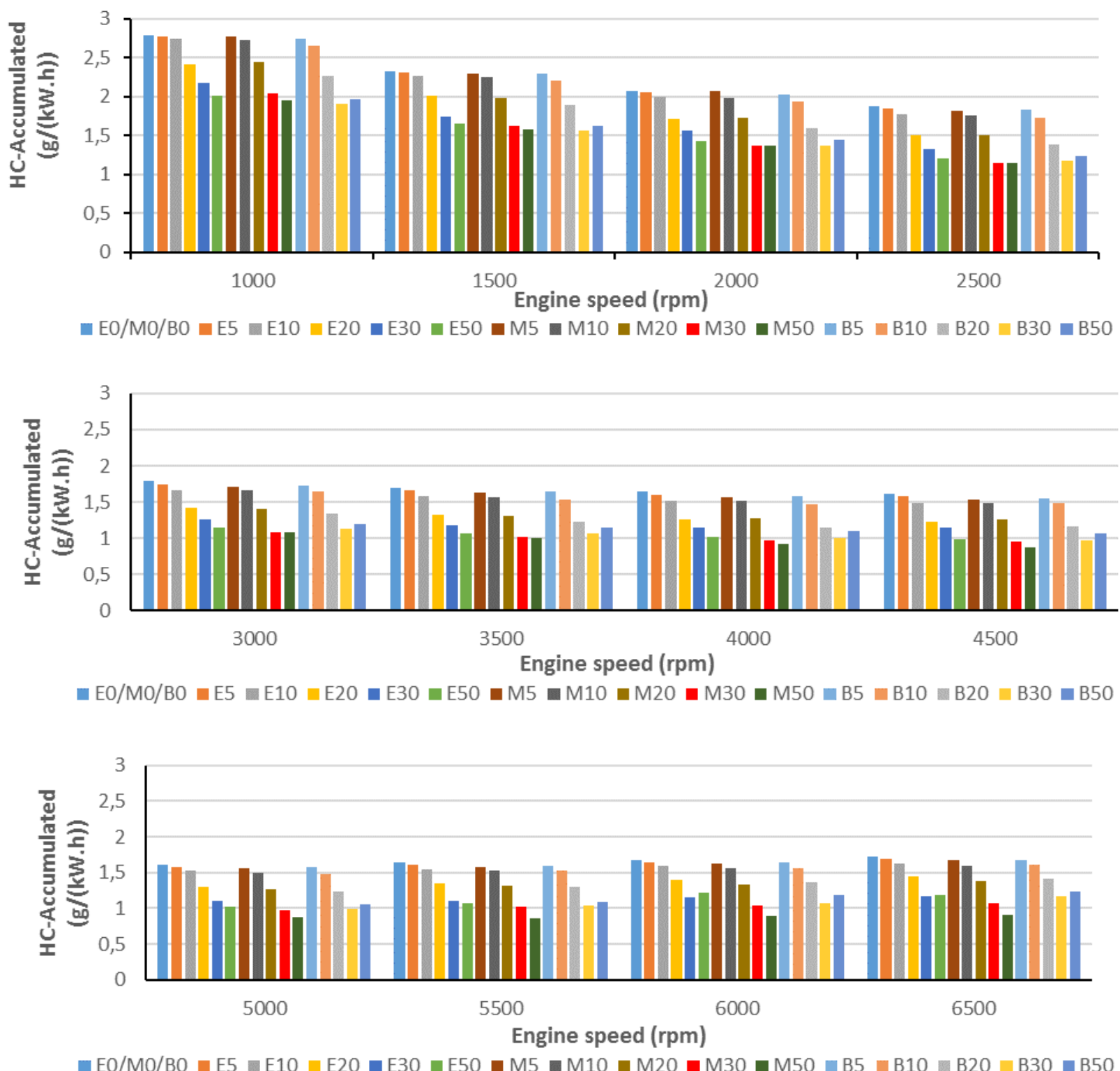

Fig. 5. Influence of ethanol, methanol and butanol gasoline blended fuels on HC emissions.

Nitrogen oxides ( $\mathrm{NO}$ and $\mathrm{NO}_{2}$ ) are formed by the oxidation of nitrogen from the air in the combustion process. An important parameter for the formation of nitrogen oxides is the combustion temperature (increased combustion temperature results in increased nitrogen oxide emissions). Therefore, its probable formation is in very high temperature regions, which are related to heat release [22]. It should be noted that nitrogen oxides $\left(\mathrm{NO}_{\mathrm{X}}\right)$ are regulated pollutants that are determined jointly, as the sum of $\mathrm{NO}$ and $\mathrm{NO}_{2}$ contents rather than as individual components [23].

The effect of the ethanol, methanol and butanol gasoline blends on NOx emissions for different engine speeds is shown in (Fig. 6). It can be seen that when ethanol and methanol percentage increases up to $30 \%$ E30 (M30), the NOx concentration increases after which it decreases with increasing the ethanol (methanol) percentage but when n-Butanol percentage increases up to 50\% (B50), the NOx concentration increase after which it decreased with increasing n-Butanol percentage. This can be explained by the improved combustion inside the cylinder resulting in an increased in-cylinder temperature.

The higher percentage of ethanol (methanol, butanol) in gasoline reduces the in-cylinder temperature. The reasons for the reduction in temperature are: 1. Latent heat of evaporation of ethanol (methanol, butanol), which decreases the incylinder temperature when they vaporizes, 2 . The more triatomic molecules are produced, the higher the gas heat capacity and the lower the combustion gas temperature will be. However the low in-cylinder temperature can also lead to an increment in the unburned combustion product. 

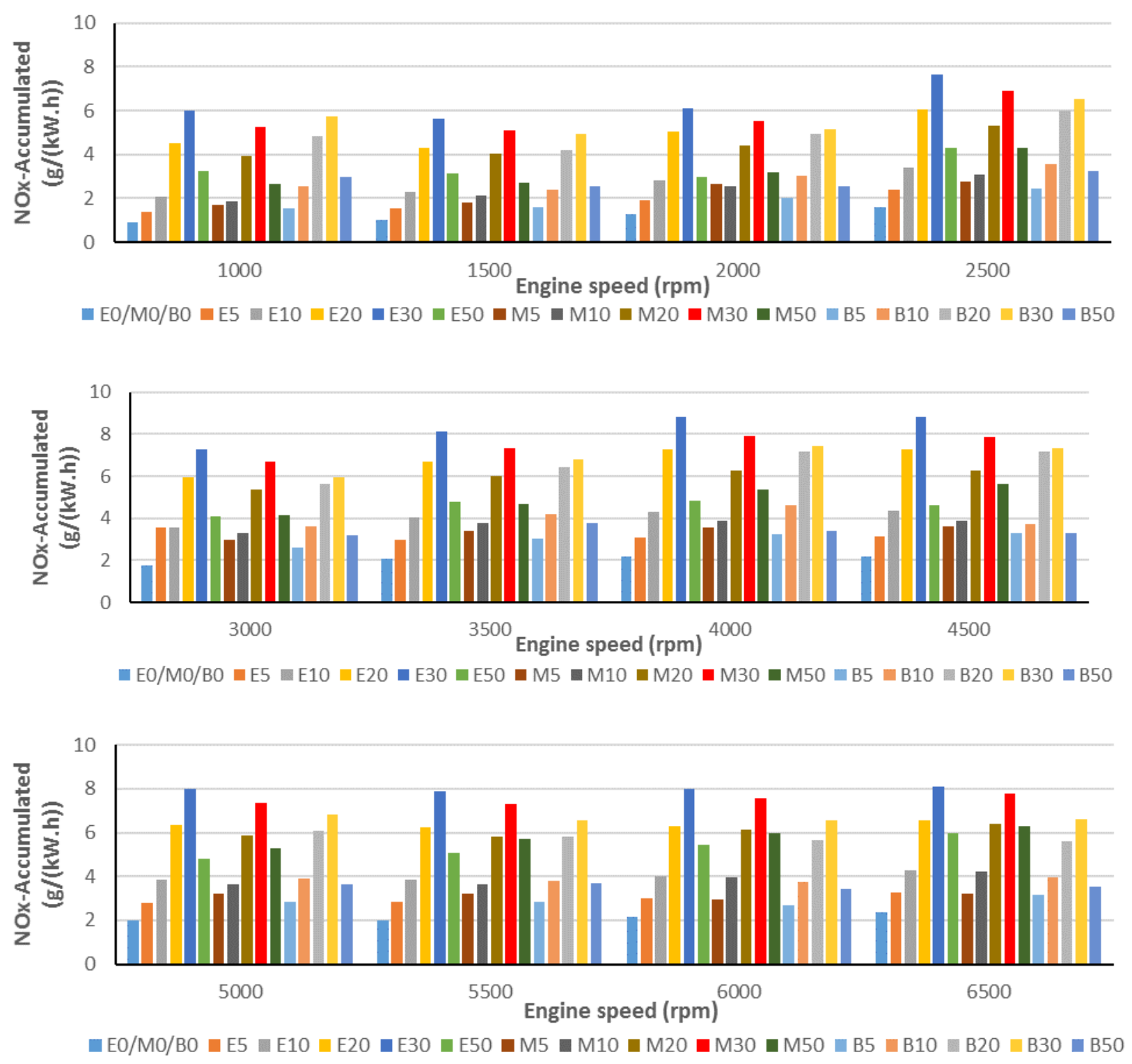

Fig. 6. Influence of ethanol, methanol and butanol gasoline blended fuels on NOx emissions.

\section{Conclusion}

The present paper demonstrates the influences of ethanol, methanol and butanol addition to gasoline on SI engine performance and emission characteristics. General results concluded from this study can be summarized as follows:

When the ethanol and butanol content in the blended fuel was increased, the engine brake power decreased for all engine speeds. When the methanol content in the blended fuel was increased (M5 and M10), the engine brake power slightly increased and when the methanol content in the blended fuel was increased (M30 and M50), the engine brake power decreased for all engine speeds. The BSFC increased as the ethanol (methanol, butanol) percentage increased. Gasoline blended fuels show lower brake power and higher BSFC than those of gasoline. Also, a slight difference exists between the BSFC when using gasoline and gasoline blended fuels (E5 (M5, B5), E10 (M10, B10) and E20 (M20, B20)).

When ethanol and methanol percentage increases, the $\mathrm{CO}$ and $\mathrm{HC}$ concentration decreases. The lowest $\mathrm{CO}$ and $\mathrm{HC}$ emissions are obtained with blended fuel containing methanol (M50).

Ethanol and methanol gasoline blends the significant increase NOx emissions with the increase of ethanol and methanol percentage. When ethanol and methanol percentage increases up to 30\% E30 (M30), the NOx concentration increases, followed by a decrease, after which it decreases with increasing ethanol (methanol) percentage.

Butanol gasoline blends the significant increase NOx emissions with the increase of butanol percentage. When butanol percentage increases up to 50\% B50, the NOx concentration increase after which it decreased with increasing butanol percentage. The lowest NOx emissions are obtained with gasoline.

Future research should focus on examining different alcohol-gasoline fuel blends and their comparison with ethanol, methanol and butanol. 


\section{Acknowledgments}

The present document has been produced with the financial assistance of the Project 2018-RU-07 "Creation of a complex mobile laboratory platform for research and approbation of environmentally friendly technical solutions".

We are also eternally grateful to AVL-AST, Graz, Austria for granting use of AVL-BOOST under the university partnership program.

\section{References}

[1] Dhamodarana G, Esakkimuthub GS., Pochareddyc YK., Sivasubramanianc H. (2017). Investigation of n-butanol as fuel in a four-cylinder MPFI SI engine, Energy, Elsevier, Vol. 125, pp. 726-735.

[2] Iliev, S. (2015). A comparison of ethanol and methanol blending with gasoline using a 1-D engine model, 25th DAAAM International Symposium on Intelligent Manufacturing and Automation, Procedia Engineering, Elsevier, Vol 100, pp. 1013-1022.

[3] Cavalcante Cordeiro de Melo, T.; Bastos, Machado G. Machado, RT. Pereira, Belchior Jr CR. Pereira PP. (2007). Thermodynamic modeling of compression, combustion and expansion processes of gasoline, ethanol and natural gas with experimental validation on a flexible fuel engine, SAE World Congress: 2007-24-0035.

[4] Dhamodaran, G.; Esakkimuthu, GS. Pochareddy, YK. (2016). Experimental study on performance, combustion, and emission behaviour of diisopropyl ether blends in MPFI SI engine. Fuel 2016; Vol. 173, pp. 37-44.

[5] Kisenyi, JM.; Savage CA, Simmoiids AC. (2004). The impact of oxygenates on exhaust emissions of six European cars. SAE Technical Paper.

[6] Agarwal, K.A. (2007). Biofuels (alcohols and biodiesel) applications as fuels for internal combustion engines, Progress in Energy and Combustion Science, Elsevier, Vol. 33, pp. 233-271.

[7] Yacoub, Y., Bara, R., Gautam, M., (1998). The performance and emission characteristics of C1-C5 alcohol-gasoline blends with matched oxygen content in a singlecylinder spark ignition engine. Proc Inst Mech Eng A - Power Energy; 212:363-79.

[8] Gautam, M., Martin, DW., (2000). Combustion characteristics of higher-alcohol/gasoline blends. Proc Inst Mech Eng; 214A:497-511.

[9] Iliev, S.; (2017). Investigation of N-Butanol Blending with Gasoline using a 1-D Engine Model, Special Session on Sustainable mobility solutions: vehicle and traffic simulation, on-road trials and EV charging, 2017; pp. 385-391.

[10] Wagner T., Gray D, Zarah BY, Kozinski AA. (1979). Practicality of alcohols as motor fuel. SAE; 1979.

[11] The Act of 25 August (2006), the system of monitoring and controlling the quality of fuels (Journal of Laws of 2006. No. 169, item. 1200, as amended.

[12] Directive of the European Parliament and Council Directive 2009/28/EC of 23 April 2009. On the promotion of energy from renewable sources and amending and subsequently repealing Directives 2001/77 / EC and 2003/30/EC.

[13] Schnepf R., Yacobucci BD. (2013). Renewable Fuel Standard (RFS): Overview and Issues.

[14] Wallner, T.; Ickes A.; Wasil J.; Sevik J.; Miers, S. (2014). 'Impact of blending gasoline with iso-butanol compared to ethanol on efficiency, performance and emissions of a recreational marine 4-stroke engine.' SAE Technical Paper 14PFL-0436. Scheduled for publication at the SAE 2014 World Congress.

[15] Altun, S., Oztop H., Oner, C., Exhaust, Y. (2013). Emissions of methanol and ethanol-unleaded gasoline blends in a spark ignition engine, Thermal science, 17 (2013), 1, pp. 291-297.

[16] Feng R., Yang J., Zhang D., Deng B., Fu J, Liu J., et al. (2013). Experimental study on SI engine fuelled with butanolgasoline blend and $\mathrm{H}_{2} \mathrm{O}$ addition. Energy Convers Manage; 74:192-200.

[17] Gravalos I., Moshou D., Gialamas T., Xyradakis P., Kateris D., Tsiropoulos Z. (2013). Emissions characteristics of spark ignition engine operating on lower-higher molecular mass alcohol blended gasoline fuels. Renew Energy, Vol. 50, pp. 27-32.

[18] Costagliola, M.M., De Simio, L., Iannaccone, S.; Prati, M.V. (2013). Combustion efficiency and engine-out emissions of an SI engine fueled with alcohol/gasoline blends. Appl. Energy 2013, Vol. 111, pp. 1162-1171.

[19] Iliev, S. (2014). Developing of a 1-D combustion model and study of engine characteristics using ethanol-gasoline blends, Proceedings of the World Congress on Engineers 2014, Vol II, WCE 2014/ 978-988-19253-5-0.

[20] Iliev, S. (2014). Developing of a 1-D combustion model and study of engine performance and exhaust emissions using ethanol-gasoline blends, IAENG Transaction of Engineering Technologies, Netherlands, Springer, 2014

[21] Egeback, KE, Henke M., Rehnlund B., Wallin M., Westerholm R. (2005). Blending of ethanol in gasoline for spark ignition engines-problem inventory and evaporative measurements. Report No. MTC 5407. AVL MTC Motortestcenter AB Box 223 SE-136 23 Haninge.

[22] Raslavicius, L., Bazaras Z. (2010). Variations in oxygenated blend composition to meet energy and combustion characteristics very similar to the diesel fuel, Fuel Processing Technology, Vol. 91, pp. 1049-1054.

[23] Egeback KE, Henke M., Rehnlund B., Wallin M., Westerholm R. (2005). Blending of ethanol in gasoline for spark ignition engines-problem inventory and evaporative measurements. Report No. MTC 5407. AVL MTC Motortestcenter AB Box 223 SE-136 23 Haninge. 